\title{
Investigation of Co-Integration between Standard and Poor Index and Dow Jones Index in the New York Financial Market
}

\author{
Ateyah Alawneh ${ }^{1}$ \\ ${ }^{1}$ College of Business, Tafila Technical University, Jordan \\ Correspondence: Ateyah Alawneh, College of Business, Tafila Technical University, Jordan. E-mail: \\ ateayh1@yahoo.com
}

Received: March 7, 2018

Accepted: March 28, 2018

Online Published: April 15, 2018

doi:10.5539/ijef.v10n5p197

URL: https://doi.org/10.5539/ijef.v10n5p197

\begin{abstract}
The study investigates the co-integration between (the S\&P 500 index)and (Dow Jones index) the DJIA by busing the method Engle-granger co-integration Test. The study use annual data from 1990 to 2016.The study examines the stability of the index of S\&P 500 and DJIA using the E-views program through a unit root test. The study found that the indicators are unstable, but they become stable when taking the first difference. This condition integrates (the S\&P 500 index) and (the DJIA index) during the long-term co-integration test. The analysis shows that there is a negative co-integration between the two variables. It should be emphasized that the short-term dynamic analysis showed a positive co-integration between both indexes. The study concluded that there is an urgent need to take into account the long-term negative co-integration between (the S\&P 500 index) and (the DJIA index) by investors in the New York market. Also, the study considers short-term positive integration between (the S\&P 500 index) and (DJIA index), which turns into a negative relationship in the long term when taking into account the markets linked with the New York market as a major global market and other international financial markets when making any financial investment. The result of this study could help users of major international financial markets in investment diversification to reduce risk.
\end{abstract}

Keywords: financial indexes, financial market, major global financial markets, major global indicators, diversification of portfolio

\section{Introduction}

The main financial indicators plays a major role in influencing the financial markets if they increase or decrease indicators on the state of financial market and indicators that contain a large industrial, service companies and contacts. In the case of market activity, the rise and stagnation that occurs in the case of financial market decline is reflected via investment decisions. The current study investigates the co-integration of financial indicators in a major global financial market, namely the New York Financial Market (NYFM), which is one of the world major financial markets like the London and Tokyo Market. The S\&P 500 index and Dow Jones (DJIA) index were also selected because they represent major indexes on the NYFM and have weight in the US Financial Market . The index of S\&P 500 was chosen because it consists of five hundred securities representing $80 \%$ of the market value of shares traded on the New York Stock Exchange (NYSE). The Dow Jones index was chosen because it $\begin{array}{llllll}\text { contains } & 30 & \text { securities, } & \text { representing } & \text { of }\end{array}$ (http://www.arab-api.org/images/training/programs/1/2004/44_C9-4.pdf)

The study investigates the co-integration of these indexes by using the Engel-Granger test method, which is used in the case of co -integration between the two variables only. Therefore, the study will investigate whether or not there is a co-integration between the S\&P 500 index and the Dow Jones index. Also the study aims to identify it is long-term or short-term co- integration in the US Financial Market. This is considered important for investors and traders in the global financial markets, especially when investors diversify in the financial market.

Several studies have been conducted on co-integration that consider some variables. Vikkram Singh, Eduardo Roca and Bin Li's study (2017) reveals that there is co-integration between global finance markets, and that the major global financial markets offered to the impact and interdependence with each other more than other market. Study by Bhuvaneshwari and Ramya's (2017) aims to determining the co-integration and the causal relationship between stock prices and the exchange rate. by using the unit root test the study found that the data were stabilized at the first difference, however it found that no integration between the study's variables. Conversely, 
Vishal and Peo's study (2014) showed the co-integration of some economic variables in the Indian stock market. The study considered four indicators in the financial market, including: SMALL CAP, CNX NIFTY, CNX NIFTY 500 and CNX MID CAP. The study used the Engel-Granger test and Johansson co-integration testing. The analysis showed that there is co-integration between the four variables.

Ferreira and Oliveira's study (2014) found an integration between the Portuguese financial market and the emerging European Markets (Italy and Ireland). They also found that the quality of integration between the European markets and mature markets (France, the UK, Germany and the United States). In addition, the Balq Abdullah and Bashir (2013) examines the existence of a long-term relationship between savings and investment in the Libyan economy; the data was taken from 1970-2005 and the study used the Engel-Granger test and Johansson co-integration testing. The analysis shows that there is no co-integration between savings and investment during the study period. This is due to the nature of the economy of the Libya which is dependent on oil as its main source. A study conducted by, Sazali, Chase, Kwan-Lyn, and Azilawati (2013) took a sample from the following countries: New Zealand and Hong Kong, Australia, Japan, South Korea, Thailand. The study used a unit root test and Engel-Granger test, and the results of the study showed that there is no long-term correlation between Indonesian stock markets and exchange rates in the study sample.

Another study was conducted based on the analysis of the co-integration of indicators in three financial markets (Assidenou, 2011). Results indicated that there was a co-integration between capital markets in Asian countries where investors couldn't avoid any external impact from these financial markets. Hande Erdinc and Joniada Milla's study (2009) assessed the fact that whether or not there is co-integration between the financial markets of the (EU) countries, France, Germany and the UK, where the study used unit root tests and co-integration tests. Through monthly data on securities for the period from January 1991 to September 2000, the study found that there is long-term co-integration between the EU countries in the study sample. Taimur (2011) by using co-integration test found that there is no co-integration of financial markets in China, Korea, Malaysia and France with the United States Financial Market where investors can make gains from investment diversification with America. Hwey-Yun and Chien-Chung (2009) identified the co-integration of stock prices and the exchange rate in Japan and Taiwan, where the results of the tests show no short-term relationship between the two countries. However, in the long run there is a positive relationship.

A review of previous studies showed the integration of relationships between financial market indicators with some countries (Taimur, 2011; Vikkram, Eduardo, \& Bin, 2017; Hande \& Joniad, 2009). There are also applied studies that focused on the variables in financial markets and monetary markets, but dealt with partial issues (e.g. Sazali, Chase, Kwan-Lyn, \& Azilawati, 2013). However, the present study is distinguished from its predecessors as the first study within the scope and science of the researcher that integrates the S\&P 500 and DJIA indices using financial data for these indicators during the study period. It is also the first study within the scope and science of the researcher to use the Engel-Granger test and the E-views software program to test co- long-term and short-term integration between the study indices in the New York financial market as one of the world's major financial markets.

The next section introduces the general framework of the study. Second two covers the theoretical framework of the study; the third section is the econometric analysis. While the fourth section contains results of the study. The fifth section presents the study recommendations, and the last section references.

\subsection{The Study Problem}

The study problem comes from the statement of the complementary relationship between the S\&P 500 index and the DJIA index of the NYFM a way to understand the financial behavior of financial indicators in the NYFM, which is one of the major financial markets in the world. Because of it's size, it affects the behavior of investors in the market and the behavior of investors in other financial markets that are linked to the NYFM, which can lead to understanding the activity of the financial market. This affects general investment decisions and consequently the general economic situation which is reinforced accordingly. The problem of the study is formulated through the following questions: 1. Is there a positive co-integration that is statistically significant in the long-term between the S\&P500 index and the DJIA index? 2. Is there a positive co-integration that is statistically significant in the short- term between the S\&P 500 index and the DJIA index?

\subsection{The Study Hypotheses}

The hypotheses of the study are formulated as following,

1). There is a positive co-integration that is statistically significant in the long-term between the $S \& P 500$ index and the DJIA index. 
2). There is a positive co-integration that is statistically significant in the short- term between the S\&P 500 index and the DJIA index.

\subsection{The Importance of the Study}

The importance of the study is highlighted by its presentation of the ways and the methods of co-integration using the Engel-Ganger test. It is important that investors should know the financial behavior of the main indicators in the long term and in the short term, which contributes to strengthening the theoretical aspect of the main financial markets, and contributes to strengthening the practical side of the field of financial markets, especially the main indicators in the global financial markets. This is a study of investors in the NYFM, which can help in understanding the behavior of investors in other financial markets interconnected with the former market.

It also helps investors diversify the financial portfolio in the NYFM and in international diversification. It also helps to understand the behavior of investment decisions and the general economic situation.

\subsection{Objectives of the Study}

This study aims to:

1). Enhance the theoretical and practical aspects of financial markets and major global indices in major financial markets through the use of the Engel-Ganger test.

2). Clarify the stability of the index of S\&P 500 and the DJIA index and degree of stability.

3). Test relationship dynamic integration in the short-term between the S\&P 500 index and the DJIA index.

4). Test long-term co-integration between the S\&P 500 index and the DJIA index.

5). Make recommendations that help investment decision makers understand the behavior of the dynamic relationship of key financial indicators in the long- term and short term.

\subsection{The Procedural Definitions}

\section{1- Dow Jones (DJIA)}

This index contains 30 securities representing 30\% of the New York Stock Exchange. (arab-api).

\section{2- Standard \& Poor (S\&P500)}

This index consists of 500 securities, representing $80 \%$ of the market value of shares traded on the New York Stock Exchange. (400 industrial companies, 40 public benefit companies, 20 transport companies and 40 companies in finance, banking and insurance) (arab-api).

\subsection{The Boundaries of the Study}

Spatial: The study will be applied to the main financial indicators in the New York financial market.

Temporal: The study will cover the period of (1990-2016) to provide a historical series of statistical financial data for the variables of the study.

\subsection{The Society and the Sample of the Study}

The study population consists of the S\&P 500 index and the DJIA index.

\section{Methodology of the Study}

The standard analytical approach will be based on the use of the Engel-Ganger test method to deal with the study data to reach the objective of the study Through the following.

\subsection{Data Sources}

The study will be based on the financial statements issued by the New York financial market during the period (1990-2016).

\subsection{Statistical Tests Used in the Study}

\subsubsection{Unit Root Test}

The purpose of conducting this test is to test the indicators of the study; this test is necessary before applying tests.

\subsubsection{Engle-Granger Co-Integration Test}

A. Test the co-integration in the long-term between the S\&P 500 and DJIA indices. 
A.1- Co-integration in the long- term goes through two steps

Step (1): Estimate the linear relationship in the normal lower squares method.

Step (2): Obtain the residuals ( $\mathrm{Et}=$ values -estimated values) obtained from the first step.

If the residual method is static at the level indicated by the existence of a co-integration between the variables, then the relationship estimated in the first step is correct yet not a misleading relationship. If the residual method is not static at the level, then it does not indicate a long-term equilibrium relationship between the variables and cannot be relied upon (Balq \& Bashir, 2013).

B.Test the co-integration in the short-term between the S\&P 500 and DJIA indices.

The short term relationship will be estimated through the following steps.

Step (1): Take the first difference of the dependent and independent variables.

Step (2): Add the extracted residue in the long-term model as an independent variable to the current model in the first step with a lag (-1).

\section{Theoretical Framework: Definition of Financial Indicators and Their Importance and the Relationship between the S\&P 500 Index and the DJIA index}

\subsection{Definition of Financial Indicators in Financial Markets and Their Importance}

\subsubsection{Definition of Financial Indicator}

The stock market index measures the level of prices in the market. It is based on the sample of the shares of establishments traded in organized and unorganized capital markets. The sample is often selected in such a way that the index can reflect the situation in which the capital market measure (http://www.arab-api.org).

When the expected movement of the index goes up, it is called the (market bull) and when the expected movement of the index is going down it is called the (market Bear).

\subsubsection{The Standard \& Poor (S\&P 500) Index}

The S\&P 500 contains five hundred securities, representing (80\%) of the market capitalization of the New York Stock Exchange (400 industrial companies, 40 public benefit companies, 20 transport companies, 40 companies in the field of finance Banks and insurance). The S\&P includes common shares listed on the New York and (NASDAQ) Stock Exchanges. It was first calculated in 1923 and is currently one of the best general indices of the US stock market and it is calculated by S\&P and Dow Jones. Standard \& Poor 500 is a weighted index of market value, with companies weighted according to the total market value of their issued shares. The higher the market weights of the company, the greater the impact on the index (https://www.argaam.com).

\subsubsection{The Dow Jones Industrial}

This index contains 30 securities, representing 30\% of the New York Stock Exchange and is the oldest indicator of the US stock market. It dates back to 1896 and tracks the movement of 30 large US companies, but currently it does not rely on industrial companies despite its name. It additionally includes companies from various categories, such as finance and consumer goods, including: Goldman Sachs, Visa and McDonald's. This index was developed by Charles Dow and was first calculated on May 26, 1896, and is now managed by S\&P Dow Jones. The Dow Jones Industrial Average is a weighted average for the price. The companies listed on the index are weighted in proportion to their share price, so the higher stocks have higher weight and therefore have a greater impact on the performance of the index. It was originally calculated by the total share price of each listed company and divided by the number of companies, so it is called the average, but the index is no longer calculated in that simple way, because over the years the divestitures and other events have made the Dow a very small number (number less than 0.2)(https://www.argaam.com).

\subsection{The Importance of Financial Indicators in the Stock Market}

Recently, there have been many usages and uses of financial indicators in the stock market to individual investors and other parties that deal with such "capital" markets, the most important are the following.

1). Giving a quick idea of the performance of the portfolio, where the investor or the investment manager can make a comparison between the change in the yield of his portfolio (positive or negative) with the change in the market index as reflecting a portfolio of good diversification without the need to follow the performance each sheet separately. If investment (for an investor) in a particular industry has its own index, then it would be better to follow that indicator.

2). Judging the performance of professional managers, according to the notion of diversification, an investor who 
has a portfolio of randomly-selected-securities can achieve a return that is almost equivalent to the market return (average rate of return on securities traded in the market) reflected in the index. This means that a professional manager who uses advanced diversification techniques is expected to achieve higher returns than average market returns.

3). Predicting the state of the market: If the analyst knows the nature of the relationship between some economic variables and the variables of the financial indicators (the so-called basic analysis), he or she may be able to predict in advance what the case of the market in the future will be. Technical and historical indicators that measure the state of the market may reveal a pattern of changes that occur. If the analyst knows this pattern, he or she can't predict future developments in the direction of price movement in the market.

4). Investors use the portfolio risk assessment to measure the systemic risk of the portfolio, the relationship between the rate of return of the risky assets and the rate of return of the market portfolio of the risk assets (www.arab-api.org)

\subsection{The Relationship between the Indicator (S\&P 500) and the (DJIA) Index}

Table (1) shows that the S\&P 500 index was at 330.22 points in 1990 , as it continued to rise and fall during the years of the study until it reached 2,238.83 points in 2016. The study note the continued rise of the DJIA index, finding that it was at 2,633.66 points in 1990, and that it reached 1,762.6 points in 2016 .

Table 1. Size of the S\&P 500 index and the DJIA index during the years of study (1990-2016)

\begin{tabular}{ccc}
\hline years & S\&P 500 & DJIA \\
\hline $\mathbf{1 9 9 0}$ & 330.22 & 2633.66 \\
$\mathbf{1 9 9 1}$ & 417.09 & 3168.83 \\
$\mathbf{1 9 9 2}$ & 435.71 & 3301.11 \\
$\mathbf{1 9 9 3}$ & 466.45 & 3754.09 \\
$\mathbf{1 9 9 4}$ & 459.27 & 3834.44 \\
$\mathbf{1 9 9 5}$ & 615.93 & 5117.12 \\
$\mathbf{1 9 9 6}$ & 740.74 & 6448.27 \\
$\mathbf{1 9 9 7}$ & 970.43 & 7908.3 \\
$\mathbf{1 9 9 8}$ & 1229.23 & 9181.43 \\
$\mathbf{2 0 9 9}$ & 1469.25 & 11497.12 \\
$\mathbf{2 0 0 1}$ & 1320.28 & 10787.99 \\
$\mathbf{2 0 0 2}$ & 1148.08 & 10021.57 \\
$\mathbf{2 0 0 3}$ & 879.82 & 8341.63 \\
$\mathbf{2 0 0 4}$ & 1111.92 & 8341.63 \\
$\mathbf{2 0 0 5}$ & 1211.92 & 10783.01 \\
$\mathbf{2 0 0 6}$ & 1248.29 & 10717.5 \\
$\mathbf{2 0 0 7}$ & 1418.3 & 12463.15 \\
$\mathbf{2 0 0 8}$ & 1468.36 & 13264.82 \\
$\mathbf{2 0 0 9}$ & 903.25 & 8776.39 \\
$\mathbf{2 0 1 0}$ & 1115.1 & 10428.05 \\
$\mathbf{2 0 1 1}$ & 1257.64 & 11577.51 \\
$\mathbf{2 0 1 2}$ & 1257.6 & 12217.56 \\
$\mathbf{2 0 1 3}$ & 1426.19 & 13104.14 \\
$\mathbf{2 0 1 4}$ & 1848.36 & 16576.66 \\
$\mathbf{2 0 1 5}$ & 2058.9 & 17098.45 \\
$\mathbf{2 0 1 6}$ & 2043.94 & 17425.03 \\
& 2238.83 & 19762.6 \\
\hline & & \\
\hline & & \\
\hline
\end{tabular}

Source: https://sa.investing.com/indices/us-30-historical-data. 


\section{$S \& P 500$}

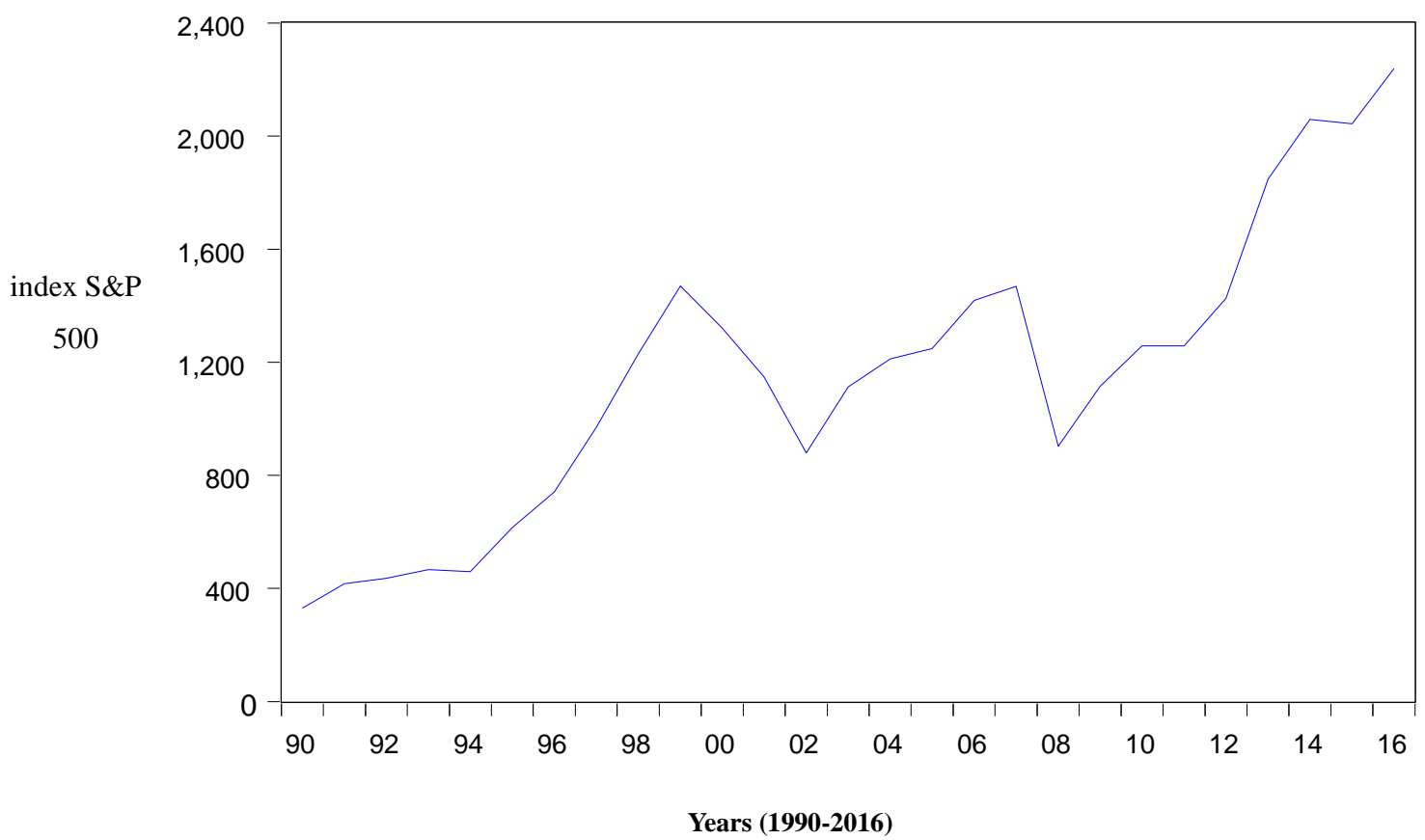

Figure 1. The graph of the index S\&P 500 during the years of study

Source: By the researcher based on the data of Table 1.

From the graph above, we see the continued growth of the index of S\&P 500 during the years of study. We also notice the rise and growth of the index until it reached the summit level in (2000) and then dropped in (2002), then rose and continued to rise until the peak reached in (2007) and the study note the continued rise and fall of the index during the years of study.

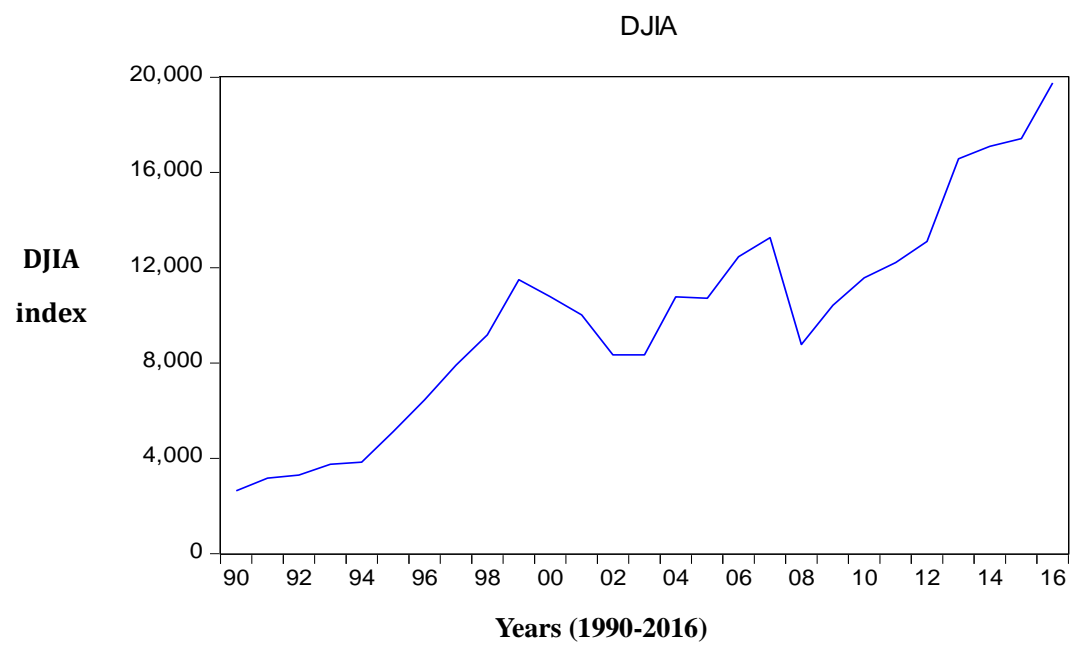

Figure 2. The DJIA chart for the years of study

Source: By the researcher based on the data of Table 1.

From the graph above, the study see the continued growth of the DJIA index during the years of study. We also notice the rise and growth of the index until the peak was reached in (2000) then decreased in 2002 and then rose and continued to rise until reaching the peak in 2007. We further notice the continued rise and fall of indicators during the years of the study; it would decrease at a certain point and then rise in height and so on. The rise and fall of the indices is due to the impact of stock indices in general on a number of factors including: corporate data and economic reports, domestic and foreign political events, wars and terrorism and natural disasters that may 
have economic effects.

\section{The correlation between the S\&P 500 index and the DJIA index is noted below as thus:}

1). The S\&P 500 index and the DJIA index reached the summit during the same years (2000) and (2007).

2). The S\&P 500 index and the DJIA index access to the lowest point during the same school years in 2002 and 2008.

3). It is noted that the relationship exists between the indicators of rise and fall during the same years.

\section{The Practical Framework of the Study: Econometric Analysis}

\subsection{Test the Stability of the S\&P 500 Index and the DJIA Index}

\subsubsection{Test the Stability of the S\&P 500 Index}

Note from Table 1 that the Dickey-Fuller test statistic is equal to $(-0.468448)$, while the critical value is at $5 \%$ equal to (-2.981038). This indicates that the series is not static as shown in Appendix 1, but the series is static by taking the first difference using the Dickey-Fuller test statistic as shown in Appendix 2. This can be summarized in Table 2 below.

Table 2. Summary of the stability test of the index of S\&P 500

\begin{tabular}{ccc}
\hline Augmented Dickey-Fuller test statistic & Test critical values(5\% level) & Result \\
\hline $\mathbf{- 0 . 4 6 8 4 4 8}$ & -2.981038 & D-F (Augmented Dickey-Fuller test statistic) $>$ T.V \\
Prob. $*(\mathbf{0 . 8 8 2 3})$ & & (Test critical values(5\% level) No Stationary \\
$\mathbf{- 4 . 3 0 0 4 5 6}$ & -2.986225 & D-F $<$ T.V Stationary \\
Prob. $*(\mathbf{0 . 0 0 0 0})$ & & \\
When making the first difference & & \\
\hline
\end{tabular}

Note from Table 2 that the index of S\&P 500 is stable after the first difference.

\subsubsection{Test the Stability of the DJIA Index}

Note from Table 3 that the Dickey-Fuller test statistic is equal to (-0.211557), which is greater than the critical value at 5\%, which equals(-2.981038). This indicates that the series is not static, as shown in Appendix 3, and the series is static by taking the first difference using the Dickey-Fuller test statistic, as shown in Appendix 4. This can be summarized in Table 3 .

Table 3. Summary of the stability test of the index of DJIA

\begin{tabular}{cccc}
\hline Augmented Dickey-Fuller test statistic & Test critical values(5\% level) & \multicolumn{2}{c}{ Result } \\
\hline $\mathbf{- 0 . 2 1 1 5 5 7}$ & -2.981038 & D-F $>$ T.V & No Stationary \\
Prob. $*(\mathbf{0 . 9 2 5 2})$ & & & \\
$-\mathbf{4 . 8 2 5 1 7 0}$ & -2.986225 & D-F<T.V & Stationary \\
Prob.*(0.0007) & & & \\
\hline
\end{tabular}

It can be noticed that, from Table 2 and Table 3, the series of S\&P 500 and the DJIA series have been stabilized after the first difference, meaning that the indicators are stabilized at the same score. This is the achievement of the first condition for the co-integration of indicators using the method of Engel-Granger test.

\subsection{The Co-Integration of the Long-Term between the S\&P 500 Index and the DJIA Index}

In order to estimate the model co-integration between the S\&P 500 index and the DJIA index we will estimate the following model, using the residual method to correct the error to estimate the model in the long term as follows.

$$
D J I A=a+B s \& p 500+E t
$$

Whereas:

DJIA: values the DJIA index during the years of study;

A: constant in the equation;

B: Regression parameter to be estimated;

S\&P 500: values of the index during the years of study; 
$\mathrm{Et}=$ DJIA - DJIA(estimated);

Where residual methods are intended to correct error and estimate the model in the long term.

The S\&P 500 is the best representation of the US market, as it contains 500 companies from large companies in the sense that it contains 500 securities representing $80 \%$ of the market value of traded shares on the New York Stock Exchange (400 industrial companies, 40 public utility companies, 20 transport companies, 40 companies in the finance, banking and insurance sectors), compared with the Dow Jones index, which contains 30 securities representing $30 \%$ of the New York Stock Exchange

The model will be estimated using the E-views program as follows. It can be noted that, from Appendix (5), the normal model is estimated where

results are shown but these results are not for the long term.

$$
\begin{gathered}
D J I A=-167.5541+8.782450 S \& P 500 \\
\mathrm{t}:(0.49) \quad(32)^{* * *}
\end{gathered}
$$

In order to estimate the integration, the model will be estimated using the following equation.

$$
E T=\text { DJIA }- \text { DJIA (estimated) }
$$

The residual values are calculated using the (E-views) program, as shown in Appendix 6. Then the integration of the subscriber are performed by using the unit root using a program (E-views) where the co-integration model was estimated in the long run and the results were shown in Appendix 7, where the value of Dickey-Fuller is not statistically significant and the constant value of the model is not statistically significant. In order to obtain the stability of the model, the first difference will use the (E-views) program. It is also noted in Appendix 8 that the model is stable, thus indicating the statistical significance of Dickey-Fuller. But the study noted that the constant is not a statistical significance, and it must be deleted, as is noted in Appendix 9 after the deletion of the constant, which gets the following form:

\begin{tabular}{|c|c|c|c|}
\hline \multicolumn{4}{|c|}{ Dependent Variable: DJIA } \\
\hline Variable & Coefficient & t- Statistic & Prob. \\
\hline D(ET(-1)) & -1.318167 & -6.7 & 0.0000 \\
\hline \multicolumn{4}{|l|}{ R- Squared: $65 \%$} \\
\hline \multicolumn{4}{|l|}{ Adjusted R- Squared: $65 \%$} \\
\hline Durbin-Watson stat: 2.03 & & & \\
\hline
\end{tabular}

$$
D J I A=-1.318167 D(E T-1)
$$

Table 4. Results of regression model

The model shows that the adjusted R-Squared (65\%), which also shows that the change in the independent variable accounts for about $(65 \%)$ of changes in the dependent variable. The Durbin-Watson stat is equal to (2.03), meaning that the model is suitable and statistically significant, where there is no problem of auto-correlation or systematic error

Note that the combined integration between the S\&P 500 index and the DJIA index is negative, whereas the S\&P 500 index increases lead to reduced DJIA in the long term. It rejects the hypothesis in which there is a positive co-integration that is statistically significant in the long term between the S\&P 500 index and the DJIA index.

\subsection{The Co-Integration of the Short-Term between the S\&P 500 Index and the DJIA Index}

In order to estimate the co-integration model between S\&P500 and DJIA, the study will use the residual method to correct the error to estimate the model in the short term by estimating the following model.

$$
D(D J I A)=a+B 1 D(P \& S 500)+B 2 \text { et }(-1)+u t
$$

Whereas:

D (DJIA): The first difference (D) DJIA;

a: constant in the equation;

B, B2: Regression parameters to be estimated;

P \& S: The first difference of S\&P 500.

Et(-1): DJIA-DJIA(estimated) where the residual methods are intended to correct the error and estimate the 
model in the short term. These are the same values that were estimated using equation number (2) but the values are lag $(-1)$.

The model of co- integration was estimated in the short term and the results as shown in Appendix (10) where it appears that the model is statistically significant, but the constant is not statistically significant. Therefore, the estimate will be regained in the short term with the deletion of the constant as in Appendix (11).

Where the results are as follows:

$$
\begin{array}{r}
D(D J I A)=7.462409 D(P \& S 500)-0.472095 E T(-1) \\
\text { T: }(13.63555)^{* * * *} \quad(-2.907086)^{* * *}
\end{array}
$$

Table 5. Results of regression model

\begin{tabular}{cccc}
\hline \multicolumn{4}{c}{ Dependent Variable: $\mathrm{D}($ DJIA $)$} \\
\hline Prob. & Coefficient & t- Statistic & Prob. \\
\hline D(P\&S500) & 7.462409 & 13.63555 & $\mathbf{0 . 0 0 0 0}$ \\
ET(-1) & -0.472095 & -2.907086 & $\mathbf{0 . 0 0 7 7}$ \\
\hline R- Squared: 86\% & & & \\
Adjusted R- Squared: $85 \%$ & & & \\
Durbin-Watson stat: 2.22 & & & \\
\hline
\end{tabular}

It is clear from the model that adjusted R-Squared (85\%) shows that the change in the independent variable accounts for about $85 \%$ of changes in the dependent variable, and that the value of Durbin-Watson stat is the model is suitable and statistically significant where there is no problem of auto-correlation or systematic error.

This equation is in for short term, where ET (-1) is added to the equation, which can be defined as a unit for the regression of the combined integration and its value $(-0.47)$ for the equilibrium at the present moment of (the DJIA index.) If the value of zero is not necessary, the equilibrium gets to equilibrium point, while the equilibrium value in the equation doesn't get to zero, so there is a balance between the two indices. The value of the error correction coefficient (equilibrium or residual index) is negative and statistically significant, and is different from zero, and we note from the regression unit where the imbalance corrects the equilibrium at an annual rate (-0.47). Also, the coefficient of S\&P 500 equals (7.46) in the above model, which means an increase of $1 \%$ in the index of S\&P 500 on S\&P $500(-1)$ leading to an average positive increase of $(7.46 \%)$ for (the DJIA index) on DJIA (-1), it accepts the hypothesis in which there is a positive co-integration, which is statistically significant in the short term between the S\&P 500 index and DJIA index.

\subsection{The Long-Term Model and Short-Term Model}

Consequently, a long-term model and a short-term model could be incorporated as follows.

$$
\mathrm{D}(D J I A)=7.462409 \mathrm{D}(\mathrm{PS} 500)-0.472095 \mathrm{ET}(-1)-\frac{1.318167 \mathrm{D}(\mathrm{ET}-1)}{\text { long-term }}
$$

The analysis shows that the long-term integration between the S\&P 500 index and the DJIA index is inverse, while the short-term co-integration between S\&P 500 index and DJIA index is positive, Also the balance between the two indices is equal (-0.47).

\section{Results}

We have come up the following results:

1). There is stability for the two indicators after the first difference and this is the first condition to achieve co-integration in the sense that the two indicators are stabilized at one degree.

2). There is a long-term negative co-integration between the two indices, which means that an increase of the S\&P 500 index leads to a lower DJIA index value in the long term, and this result helps investors decide to diversify their long-term investment portfolio.

3). There is a long-term negative co-integration between the two indices, which means that an increase of (the S\&P 500 index) leads to a lower (DJIA index) value in the long term, and this result helps investors decide to diversify in investment portfolio. It rejects the hypothesis in which there is a positive co-integration statistically significant in the long term between (the S\&P 500 index) and the (DJIA index).

4). There is a positive dynamic short-term correlation between the index of S\&P 500 and DJIA, which means a one percent increase of (the index S\&P 500)on S\&P 500 (-1) leads to a positive increase of (7.46\%) for DJIA on 
DJIA (-1). It accepts the hypothesis in which there is a positive co-integration which statistically significant in the short term between (the S\&P 500 index )and (DJIA index).

5). The study Recognized the balance between (the S\&P 500index) and( DJIA index) at an annual rate (-0.47).

\section{Recommendations}

1). The long-term negative correlation between the S\&P 500 index and the DJIA index should be taken into account by investors in the New York market, especially when considering diversification of the portfolio.

2). There is an urgent need to consider the short-term positive co-integration relationship between (the S\&P 500 index) and (the DJIA index), which turns into a long-term negative relationship by dealers.

3). There is a necessity to consider the relationship of long- and short-term integration between the two indicators when diversifying investment portfolios or making any financial investment in the market New York or other global markets linked to the New York financial market.

4). There must be a forecasting of the changes between the S\&P 500 index and (the DJIA index) as well as their impact on the markets linked to the New York market as a major global market and other international financial markets.

5) Conduct future studies on the co- integration of other indicators in the New York financial market. Conducting studies on the co-integration of key indicators in the New York financial market and indices in markets around the world. Also conducting studies in the co- integration between New York financial market and other countries.

\section{References}

Balq, A., \& Bashir. (2013). The Relationship between Investment and Savings in the Libyan Economy for the Period (1970-2005). The Whole Journal, 15(2).

Bhuvaneshwari, D., \& Ramya, K. (2017). Cointegration and Causality between Stock Prices and Exchange Rate: Empirical Evidence from India. (Sdmimd) Journal of Management. https://doi.org/10.18311/sdmimd/2017/15720

Hande, E., \& Joniada, M. (2009). Analysis of Co-integration inCapital Markets of France, Germany and United Kingdom. Economics \& Business Journal: Inquiries \& Perspectives, 2(1).

Hwey-Yun, Y., \& Chien-Chung, N. (2009). Testing for co-integration with threshold effect between stock prices and exchange rates in Japan and Taiwan. Japan and the World Economy, 21, 292-300. https://doi.org/10.1016/j.japwor.2008.09.001

Komlavi, E. A. (2011). Cointegration of Major Stock Market Indices during the 2008 Global Financial Distress. International Journal of Economics and Finance, 3(2).

Nuno, B. F., \& Manuela, M. O. (2014). An Analysis of Equity Markets Co-integration in the European Sovereign Debt Crisis. Open Journal of Finance, 1(1).

Sazali, A., Chase, W., Kwan-Lyn, L., \& Azilawati, B. (2013). Co-integration between stock prices and exchange rates in Asia-Pacific countries. Investment Management and Financial Innovations, 10(2).

Taimur, A. K. (2011). Co-integration of International Stock Markets: An Investigation of Diversification Opportunities. Comprehensive Exercise in Economics Carleton College.

Vikkram, S., Eduardo, R., \& Bin, L. (2017). Co-integration network ksinstoc kmarkets. Applied Economics, Rutledge Taylor and Francis Group.

Vishal, P. (2014). Investigating co-integration between some Indian stock indices. International Journal of Scientific and Engineering Research, 5(1).

Website:

https://www.argaam.com/ar/article/articledetail/id/3699431

http://www.arab-api.org/images/training/programs/1/2004/44_C9-4.pdf

https://sa.investing.com/indices/us-30-historical-data

https://us.spindices.com/documents/methodologies/methodology-sp-us-indices.pdf

\section{Notes}

Note 1 . The short-term sequence of the short-term pattern must have a negative value and a statistical function 
until the dynamic model is stabilized in the short term.

Note 2. The Dickey-Fuller values are compared with McKinnon tables in a single independent variable (-3.34), since the Dickey-Fuller value should be less than (-3.34) statistic (McKinnon) to be statistically significant. Dickey-Fuller is equal to (-6.7), which is less than the statistic (McKinnon). as shown in appendix (12).

\section{Appendix 1}

Null Hypothesis: S\&P500 has a unit root

Exogenous: Constant

Lag Length: 0 (Automatic - based on SIC, maxlag=6)

\begin{tabular}{|c|c|c|c|}
\hline Prob.* & t-Statistic & & \\
\hline \multirow[t]{4}{*}{0.8823} & -0.468448 & Fuller test st & istic \\
\hline & -3.711457 & $1 \%$ level & Test critical values: \\
\hline & -2.981038 & $5 \%$ level & \\
\hline & -2.629906 & $10 \%$ level & \\
\hline
\end{tabular}

Augmented Dickey-Fuller Test Equation

Dependent Variable: D(S\&P500)

Method: Least Squares

Date: 11/16/17 Time: 16:40

Sample (adjusted): 19912016

Included observations: 26 after adjustments

\begin{tabular}{lllcc}
\hline Prob. & t-Statistic & Std. Error & Coefficient & Variable \\
\hline 0.6437 & -0.468448 & 0.083690 & -0.039204 & S\&P500(-1) \\
0.2580 & 1.158642 & 100.9054 & 116.9132 & C \\
\hline Mean dependent var & 73.40808 & R-squared & 0.009061 \\
S.D. dependent var & 198.0291 & Adjusted R-squared & -0.032229 \\
Akaike info criterion & 13.52023 & S.E. of regression & 201.1949 \\
Schwarz criterion & 13.61701 & Sum squared resid & 971505.1 \\
Hannan-Quinn criter. & 13.54810 & Log likelihood & -173.7630 \\
Durbin-Watson stat & 1.734772 & F-statistic & 0.219443 \\
& & Prob(F-statistic) & 0.643691 \\
\hline
\end{tabular}

\section{Appendix 2.}

\begin{tabular}{|c|c|c|c|c|}
\hline $\begin{array}{l}\text { Null Hypothesi } \\
\text { Exogenous: Co } \\
\text { Lag Length: } 0\end{array}$ & $\begin{array}{l}(\mathrm{S} \& \mathrm{P} 500) 1 \\
\text { ant } \\
\text { tomatic - ba }\end{array}$ & $\begin{array}{l}\text { a unit root } \\
\text { on SIC, maxla }\end{array}$ & & \\
\hline Prob.* & $\mathrm{t}-$ Statistic & & & \\
\hline \multirow[t]{4}{*}{0.0026} & -4.300456 & \multicolumn{3}{|c|}{ Augmented Dickey-Fuller test statistic } \\
\hline & -3.724070 & & $1 \%$ level & Test critical values: \\
\hline & -2.986225 & & $5 \%$ level & \\
\hline & -2.632604 & & $10 \%$ level & \\
\hline \multicolumn{5}{|c|}{ *MacKinnon (1996) one-sided p-values. } \\
\hline \multirow{2}{*}{\multicolumn{5}{|c|}{ Augmented Dickey-Fuller Test Equation }} \\
\hline & & \multicolumn{3}{|c|}{ Dependent Variable: D(SP500,2) } \\
\hline \multicolumn{5}{|c|}{ Method: Least Squares } \\
\hline \multicolumn{5}{|c|}{ Date: $11 / 16 / 17 \quad$ Time: $16: 42$} \\
\hline \multicolumn{5}{|c|}{ Sample (adjusted): 19922016} \\
\hline \multicolumn{5}{|c|}{ Included observations: 25 after adjustments } \\
\hline Prob. & t-Statistic & Std. Error & Coefficient & Variable \\
\hline 0.0003 & -4.300456 & 0.209092 & -0.899190 & $\mathrm{D}(\mathrm{S} \& \mathrm{P} 500(-1))$ \\
\hline 0.1432 & 1.515974 & 43.50946 & 65.95922 & $\mathrm{C}$ \\
\hline 4.320800 & \multicolumn{2}{|c|}{ Mean dependent var } & 0.445702 & R-squared \\
\hline 270.0824 & \multicolumn{2}{|c|}{ S.D. dependent var } & 0.421602 & Adjusted R-squared \\
\hline 13.56446 & \multicolumn{2}{|c|}{ Akaike info criterion } & 205.4044 & S.E. of regression \\
\hline 13.66197 & \multicolumn{2}{|c|}{ Schwarz criterion } & 970392.3 & Sum squared resid \\
\hline 13.59150 & \multicolumn{2}{|c|}{ Hannan-Quinn criter. } & -167.5557 & Log likelihood \\
\hline \multirow{2}{*}{1.943958} & \multirow{2}{*}{\multicolumn{2}{|c|}{ Durbin-Watson stat }} & 18.49392 & F-statistic \\
\hline & & & 0.000266 & Prob(F-statistic) \\
\hline
\end{tabular}


Appendix 3.

Null Hypothesis: DJIA has a unit root

Exogenous: Constant

Lag Length: 0 (Automatic - based on SIC, maxlag=6)

\begin{tabular}{|c|c|c|c|}
\hline Prob.* & $\mathrm{t}$-Statistic & & \\
\hline \multirow[t]{4}{*}{0.9252} & -0.211557 & Augmented Dickey-Fuller test stat & stic \\
\hline & -3.711457 & $1 \%$ level & Test critical values: \\
\hline & -2.981038 & $5 \%$ level & \\
\hline & -2.629906 & $10 \%$ level & \\
\hline
\end{tabular}

*MacKinnon (1996) one-sided p-values.

Augmented Dickey-Fuller Test Equation

Dependent Variable: D(DJIA)

Method: Least Squares

Date: 11/16/17 Time: 16:37

Sample (adjusted): 19912016

Included observations: 26 after adjustments

\begin{tabular}{ccccc}
\hline Prob. & t-Statistic & Std. Error & Coefficient & Variable \\
\hline 0.8342 & -0.211557 & 0.073347 & -0.015517 & DJO(-1) \\
0.3022 & 1.054312 & 765.6874 & 807.2738 & C \\
\hline 658.8054 & \multicolumn{2}{c}{ Mean dependent var } & 0.001861 & R-squared \\
1531.309 & S.D. dependent var & -0.039728 & Adjusted R-squared \\
17.61840 & Akaike info criterion & 1561.430 & S.E. of regression \\
17.71517 & Schwarz criterion & 58513530 & Sum squared resid \\
17.64626 & Hannan-Quinn criter. & -227.0391 & Log likelihood \\
1.986143 & Durbin-Watson stat & 0.044757 & F-statistic \\
& & 0.834239 & Prob(F-statistic) \\
\hline
\end{tabular}

Appendix 4.

\begin{tabular}{|c|c|c|c|c|}
\hline $\begin{array}{l}\text { Null Hypothesi } \\
\text { Exogenous: Co } \\
\text { Lag Length: } 0\end{array}$ & $\begin{array}{l}\text { JIA) has a un } \\
\text { natic - based }\end{array}$ & SIC, maxlag $=6$ & & \\
\hline Prob.* & t-Statistic & & & \\
\hline \multirow{4}{*}{0.0007} & -4.825170 & \multicolumn{3}{|c|}{ Augmented Dickey-Fuller test statistic } \\
\hline & -3.724070 & & $1 \%$ level & Test critical values: \\
\hline & -2.986225 & & $5 \%$ level & \\
\hline & -2.632604 & & $10 \%$ level & \\
\hline \multicolumn{5}{|c|}{ *MacKinnon (1996) one-sided p-values. } \\
\hline \multicolumn{5}{|c|}{ Augmented Dickey-Fuller Test Equation } \\
\hline \multicolumn{5}{|c|}{ Dependent Variable: D(DJIA,2) } \\
\hline \multicolumn{5}{|c|}{ Method: Least Squares } \\
\hline \multicolumn{5}{|c|}{ Date: $11 / 16 / 17 \quad$ Time: $16: 38$} \\
\hline \multicolumn{5}{|c|}{ Sample (adjusted): 19922016} \\
\hline \multicolumn{5}{|c|}{ Included observations: 25 after adjustments } \\
\hline Prob. & t-Statistic & Std. Error & Coefficient & Variable \\
\hline 0.0001 & -4.825170 & 0.213800 & -1.031623 & $\mathrm{D}(\mathrm{DJO}(-1))$ \\
\hline 0.0588 & 1.988160 & 343.2625 & 682.4607 & $\mathrm{C}$ \\
\hline 72.09600 & \multicolumn{2}{|c|}{ Mean dependent var } & 0.503049 & R-squared \\
\hline 2215.670 & \multicolumn{2}{|c|}{ S.D. dependent var } & 0.481443 & Adjusted R-squared \\
\hline 17.66441 & \multicolumn{2}{|c|}{ Akaike info criterion } & 1595.524 & S.E. of regression \\
\hline 17.76192 & \multicolumn{2}{|c|}{ Schwarz criterion } & 58551060 & Sum squared resid \\
\hline 17.69146 & \multicolumn{2}{|c|}{ Hannan-Quinn criter. } & -218.8051 & Log likelihood \\
\hline \multirow[t]{2}{*}{1.958756} & \multirow{2}{*}{\multicolumn{2}{|c|}{ Durbin-Watson stat }} & 23.28227 & F-statistic \\
\hline & & & 0.000072 & Prob(F-statistic) \\
\hline
\end{tabular}

\section{Appendix 5.}

Dependent Variable: DJIA

Method: Least Squares

Date: 11/16/17 Time: 19:22

Sample: 19902016

Included observations: 27 


\begin{tabular}{clccc}
\hline Prob. & t-Statistic & Std. Error & Coefficient & Variable \\
\hline 0.0000 & 32.49358 & 0.270283 & 8.782450 & S\&P500 \\
0.6268 & -0.492323 & 340.3339 & -167.5541 & C \\
\hline 9945.632 & Mean dependent var & 0.976870 & R-squared \\
4612.986 & S.D. dependent var & 0.975944 & Adjusted R-squared \\
16.05494 & Akaike info criterion & 715.4670 & S.E. of regression \\
16.15092 & Schwarz criterion & 12797325 & Sum squared resid \\
16.08348 & Hannan-Quinn criter. & -214.7416 & Log likelihood \\
1.039189 & Durbin-Watson stat & 1055.833 & F-statistic \\
& & 0.000000 & Prob(F-statistic) \\
\hline
\end{tabular}

\section{Appendix 6.}

$\begin{array}{ll}-98.926427 & 1990 \\ -326.68783 & 1991 \\ -357.93704 & 1992 \\ -174.92954 & 1993 \\ -31.521556 & 1994 \\ -124.70012 & 1995 \\ 110.31234 & 1996 \\ -446.89853 & 1997 \\ -1446.6665 & 1998 \\ -1238.9401 & 1999 \\ -639.74854 & 2000 \\ 106.16929 & 2001 \\ 782.20924 & 2002 \\ -1256.1973 & 2003 \\ 306.93771 & 2004 \\ -77.989989 & 2005 \\ 174.55574 & 2006 \\ 536.57631 & 2007 \\ 1011.1964 & 2008 \\ 802.29448 & 2009 \\ 699.90411 & 2010 \\ 1340.3054 & 2011 \\ 746.25222 & 2012 \\ 511.08544 & 2013 \\ -816.18151 & 2014 \\ -358.21606 & 2015 \\ 267.74232 & 2016\end{array}$

\section{Appendix 7.}

Null Hypothesis: ET has a unit root

Exogenous: Constant

Lag Length: 0 (Automatic - based on SIC, maxlag=6)

\begin{tabular}{|c|c|c|c|}
\hline Prob.* & $\mathrm{t}$-Statistic & & \\
\hline \multirow[t]{4}{*}{0.0597} & -2.894024 & Augmented Dickey-Fuller test stat & stic \\
\hline & -3.711457 & $1 \%$ level & Test critical values: \\
\hline & -2.981038 & $5 \%$ level & \\
\hline & -2.629906 & $10 \%$ level & \\
\hline
\end{tabular}

Augmented Dickey-Fuller Test Equation

Dependent Variable: D(ET)

Method: Least Squares

Date: 11/16/17 Time: 19:28

Sample (adjusted): 19912016

Included observations: 26 after adjustments

\begin{tabular}{ccccc}
\hline Prob. & t-Statistic & Std. Error & Coefficient & Variable \\
\hline 0.0080 & -2.894024 & 0.179648 & -0.519906 & ET(-1) \\
0.9451 & 0.069610 & 125.6827 & 8.748770 & C \\
\hline 14.10264 & \multicolumn{2}{c}{ Mean dependent var } & 0.258696 & R-squared \\
\hline
\end{tabular}




\begin{tabular}{lccc}
\hline 729.2098 & S.D. dependent var & 0.227808 & Adjusted R-squared \\
15.83708 & Akaike info criterion & 640.7891 & S.E. of regression \\
15.93386 & Schwarz criterion & 9854656. & Sum squared resid \\
15.86495 & Hannan-Quinn criter. & -203.8821 & Log likelihood \\
2.046243 & Durbin-Watson stat & 8.375373 & F-statistic \\
& & 0.007971 & Prob(F-statistic) \\
\hline
\end{tabular}

\section{Appendix 8.}

Null Hypothesis: D(ET) has a unit root

Exogenous: Constant

Lag Length: 0 (Automatic - based on SIC, maxlag=6)

\begin{tabular}{cccc}
\hline Prob. $^{*}$ & $\mathrm{t}-$ Statistic & & \\
\hline 0.0000 & -6.572767 & Augmented Dickey-Fuller test statistic \\
& -3.724070 & $1 \%$ level & Test critical values: \\
& -2.986225 & $5 \%$ level & \\
& -2.632604 & $10 \%$ level & \\
\hline
\end{tabular}

*MacKinnon (1996) one-sided p-values.

Augmented Dickey-Fuller Test Equation

Dependent Variable: D(ET,2)

Method: Least Squares

Date: 11/16/17 Time: 19:30

Sample (adjusted): 19922016

Included observations: 25 after adjustments

\begin{tabular}{ccccc}
\hline Prob. & t-Statistic & Std. Error & Coefficient & Variable \\
\hline 0.0000 & -6.572767 & 0.200487 & -1.317756 & D(ET(-1)) \\
0.8882 & 0.142178 & 144.0555 & 20.48157 & C \\
\hline 34.14879 & \multicolumn{2}{c}{ Mean dependent var } & 0.652575 & R-squared \\
1196.140 & S.D. dependent var & 0.637469 & Adjusted R-squared \\
16.07356 & Akaike info criterion & 720.2023 & S.E. of regression \\
16.17107 & Schwarz criterion & 11929901 & Sum squared resid \\
16.10060 & Hannan-Quinn criter. & -198.9195 & Log likelihood \\
2.039182 & Durbin-Watson stat & 43.20127 & F-statistic \\
& & 0.000001 & Prob(F-statistic) \\
\hline
\end{tabular}

\section{Appendix 9.}

Null Hypothesis: D(ET) has a unit root

Exogenous: None

Lag Length: 0 (Automatic - based on SIC, maxlag=6)

\begin{tabular}{cccc}
\hline Prob.* $^{*}$ & t-Statistic & & \\
\hline 0.0000 & -6.713979 & Augmented Dickey-Fuller test statistic \\
& -2.660720 & $1 \%$ level & Test critical values: \\
& -1.955020 & $5 \%$ level & \\
& -1.609070 & $10 \%$ level & \\
\hline
\end{tabular}

*MacKinnon (1996) one-sided p-values.

Augmented Dickey-Fuller Test Equation

Dependent Variable: D(ET,2)

Method: Least Squares

Date: 11/16/17 Time: 19:33

Sample (adjusted): 19922016

Included observations: 25 after adjustments

\begin{tabular}{ccccc}
\hline Prob. & t-Statistic & Std. Error & Coefficient & Variable \\
\hline 0.0000 & -6.713979 & 0.196332 & -1.318167 & D(ET(-1)) \\
\hline 34.14879 & Mean dependent var & 0.652269 & R-squared \\
1196.140 & S.D. dependent var & 0.652269 & Adjusted R-squared \\
15.99444 & Akaike info criterion & 705.3482 & S.E. of regression \\
16.04319 & Schwarz criterion & 11940386 & Sum squared resid \\
16.00796 & Hannan-Quinn criter. & -198.9305 & Log likelihood \\
& & 2.036683 & Durbin-Watson stat \\
\hline
\end{tabular}




\section{Appendix 10.}

\begin{tabular}{|c|c|c|c|c|}
\hline \multicolumn{5}{|c|}{ Dependent Variable: D(DJIA) } \\
\hline \multicolumn{5}{|c|}{ Method: Least Squares } \\
\hline \multicolumn{5}{|c|}{ Date: $11 / 16 / 17 \quad$ Time: 19:43 } \\
\hline \multicolumn{5}{|c|}{ Sample (adjusted): 19912016} \\
\hline \multicolumn{5}{|c|}{ Included observations: 26 after adjustments } \\
\hline Prob. & t-Statistic & Std. Error & Coefficient & Variable \\
\hline 0.0000 & 12.37439 & 0.585946 & 7.250724 & $\mathrm{D}(\mathrm{S} \& \mathrm{P} 500)$ \\
\hline 0.0093 & -2.839382 & 0.162654 & -0.461836 & $\mathrm{ET}(-1)$ \\
\hline 0.3236 & 1.008708 & 120.7364 & 121.7878 & $\mathrm{C}$ \\
\hline 658.8054 & \multicolumn{2}{|c|}{ Mean dependent var } & 0.870402 & R-squared \\
\hline 1531.309 & \multicolumn{2}{|c|}{ S.D. dependent var } & 0.859132 & Adjusted R-squared \\
\hline 15.65386 & \multicolumn{2}{|c|}{ Akaike info criterion } & 574.7358 & S.E. of regression \\
\hline 15.79903 & \multicolumn{2}{|c|}{ Schwarz criterion } & 7597387. & Sum squared resid \\
\hline 15.69567 & \multicolumn{2}{|c|}{ Hannan-Quinn criter. } & -200.5002 & Log likelihood \\
\hline \multirow[t]{2}{*}{2.343840} & \multirow{2}{*}{\multicolumn{2}{|c|}{ Durbin-Watson stat }} & 77.23583 & F-statistic \\
\hline & & & 0.000000 & $\operatorname{Prob}($ F-statistic $)$ \\
\hline
\end{tabular}

\section{Appendix 11.}

\begin{tabular}{|c|c|c|c|c|}
\hline \multicolumn{5}{|c|}{ Dependent Variable: D(DJO) } \\
\hline \multicolumn{5}{|c|}{ Method: Least Squares } \\
\hline \multicolumn{5}{|c|}{ Date: $11 / 16 / 17 \quad$ Time: 19:44 } \\
\hline \multicolumn{5}{|c|}{ Sample (adjusted): 19912016} \\
\hline \multicolumn{5}{|c|}{ Included observations: 26 after adjustments } \\
\hline Prob. & t-Statistic & Std. Error & Coefficient & Variable \\
\hline 0.0000 & 13.63555 & 0.547276 & 7.462409 & $\mathrm{D}(\mathrm{S} \& \mathrm{P} 500)$ \\
\hline 0.0077 & -2.907086 & 0.162395 & -0.472095 & $\mathrm{ET}(-1)$ \\
\hline 658.8054 & Mean dependent var & \multicolumn{3}{|c|}{$0.864669 \mathrm{R}$-squared } \\
\hline 1531.309 & S.D. dependent var & \multicolumn{3}{|c|}{ 0.859030 Adjusted R-squared } \\
\hline 15.62023 & Akaike info criterion & \multicolumn{3}{|c|}{ 574.9452S.E. of regression } \\
\hline 15.71701 & Schwarz criterion & \multicolumn{3}{|c|}{ 7933487. Sum squared resid } \\
\hline 15.64810 & Hannan-Quinn criter. & \multirow{2}{*}{\multicolumn{3}{|c|}{$\begin{array}{l}\text {-201.0630Log likelihood } \\
\text { 2.220201Durbin-Watson stat }\end{array}$}} \\
\hline & & & & \\
\hline
\end{tabular}

\section{Appendix 12.}

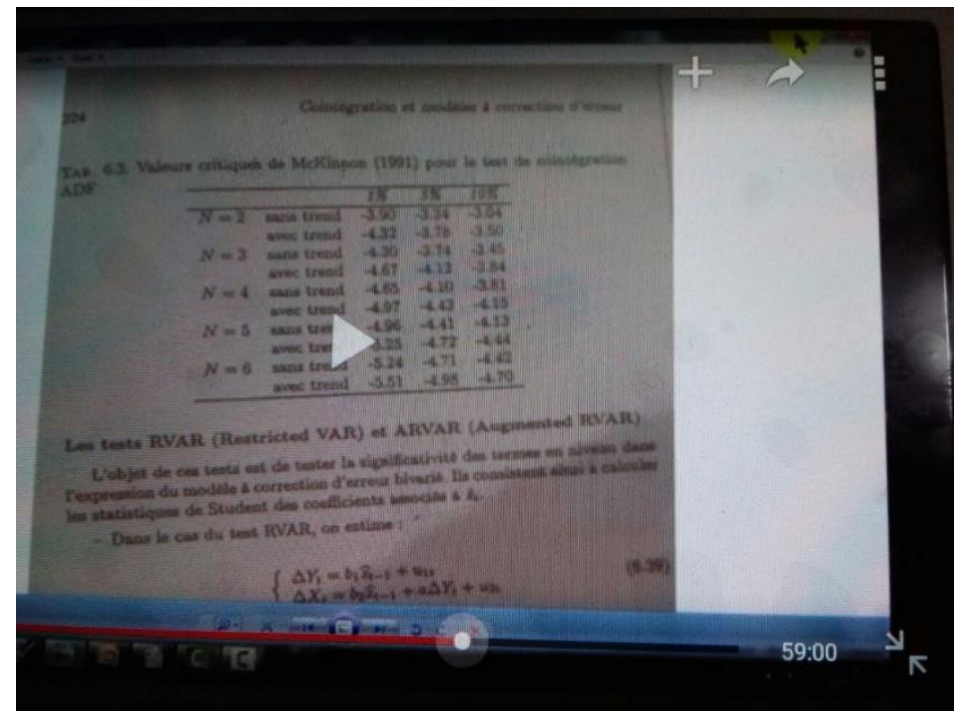

\section{Copyrights}

Copyright for this article is retained by the author(s), with first publication rights granted to the journal.

This is an open-access article distributed under the terms and conditions of the Creative Commons Attribution license (http://creativecommons.org/licenses/by/4.0/). 